\title{
REPORT ON VETERINARY MATTERS, BIRTHS AND DEATHS AT THE AMSTERDAM ZOO - 1967 TO 1973
}

\author{
by \\ A. H. M. ERKEN \\ Veterinary Surgeon of the Royal Zoological Society "Natura Artis Magistra", Amsterdam, \\ The Netberlands \\ $\&$ \\ E. F. JACOBI \\ Former Director of the Royal Zoological Society "Natura Artis Magistra", Amsterdam, \\ The Netherlands
}

\begin{abstract}
Every new mammal or bird in the Amsterdam zoo, without exception, is kept in quarantaine for some weeks and until necessary standard checks are done. The number of mammals in the collection during the period 1967-1973 varied between 729 and 858 belonging to 172 to 208 species. In birds these figures were 1571 and 1803 specimens of 391 to 520 species (table I). The average percentage of deaths in mammals was $12.4 \%$ (table II) and in birds $13 \%$ (table III).

The causes of death (tables IV and V) are arranged under 15 headings for mammals and under 18 for birds; both numbers and percentages are given. During 1967, 1968, and 1969 there were many cases of Yersinia pseudotuberculosis in the nocturnal house. The troubles only stopped after vaccination of all animals already present in the house and of the new ones before housing them. Cases of non-identified infections in psittacine birds ( 53 victims) and penguins (19 victims) are provided. The same holds true for a skin disease in apes and diabetes in ruminants. $A$ rather detailed report is given on cowpox in indian elephants in 1973. The three females of different age were affected; the male stayed free. All animals recovered after periods ranging from 17 to 57 days. One elephant had serious foot troubles in the same period, the most serious at the left forefoot. It took about 6 weeks before all animals recovered completely.

The survival rate of newborn mammals fluctuated between $59 \%$ and $66 \%$, at a number of births fluctuating from 164 to 249 a year (table VI). The low rate of $56 \%$ for wild ruminants could be raised to $67 \%$ by feeding extra minerals to pregnant and nursing females. In birds hatched (table VII) the survival rates varied between $49 \%$ and $75 \%$. The low figure is caused by the very bad results with ducks (in 1969 only $25 \%$ survival). By changing the accomodation we brought the figure for ducks up to $83 \%$ at the end of the period reported upon.
\end{abstract}

\section{INTRODUCTION}

This publication is a continuation of an earlier paper with the same title covering the years 19591966 (Jacobi \& Smits, 1968). Extensive reports on losses in zoo animals are rare but we think it worthwhile publishing these figures. It can be very useful for other zoos to be able to compare results.

In the period described the reconstruction of our zoo was progressing very slowly because of lack of funds. For this reason the accommodation for the veterinarian was still far from ideal. A rebuilt stable served as a room for dealing with sick or injured animals and part of the quarantine quarters was used for animals which had to be isolated, although this is something we do as little as possible, because the stress for animals in unfamiliar surroundings, with an unknown keeper, can have worse effects than the disease itself.

\section{ORGANISATION OF VETERINARY CARE}

The veterinarian works part-time at the zoo and is available several hours a day. His assistant-veterinarian takes over when he is off duty. The fact that his private practice consists of small animals and horses keeps him in touch with many problems outside the zoo. Moreover his practice gives him the opportunity to maintain an acceptable level of surgical skill.

Parasitological examination of faecal samples is carried out by the Department of Tropical Hygiene of the Royal Tropical Institute in Amsterdam. Post-mortems on small animals are carried out at Utrecht University by the special department for zoo animals of the Veterinary Pathological Institute. The veterinary pathologist of the Cancer Institute "Antoni van Leeuwenhoek Huis" in Am- 
sterdam performs post-mortems on parts of the larger animals. Human medical specialists are available for consultation and advice if necessary.

Every new mammal or bird, without exception, goes into isolation for some weeks. The standard rule is to check the animals for behaviour, general appearance, feeding habits, control of parasites, if necessary bacteriological investigation, all of which may be followed by treatment of disorders. When the veterinarian declares the animal to be as free as possible from diseases or parasitism it will enter the collection.

TABLE I

Mammals and birds in collection on December 31.

\begin{tabular}{llrrrrrrrr}
\hline Year & & 1967 & 1968 & 1969 & 1970 & 1971 & 1972 & 1973 \\
\hline Mammals & $\begin{array}{l}\text { species \& } \\
\text { subspecies }\end{array}$ & 208 & 208 & 203 & 200 & 191 & 183 & 172 \\
& $\begin{array}{l}\text { number } \\
\text { Birds }\end{array}$ & 820 & 814 & 832 & 824 & 858 & 729 & 769 \\
& $\begin{array}{l}\text { species \& } \\
\text { subspecies }\end{array}$ & 482 & 499 & 520 & 496 & 426 & 391 & 390 \\
& $\begin{array}{l}\text { number } \\
\text { number }\end{array}$ & 1673 & 1803 & 1782 & 1634 & 1571 & 1650 \\
\hline
\end{tabular}

\section{THE COLLECTION}

When comparing mortality rates it must be borne in mind that our zoo has a rather large collection, with a lot of small mammals with a short span of life and many delicate animals and birds. The death rate will always be higher than in a zoo with a smaller collection and hardier residents.

TABLE II

Number and percentage of deaths of resident mammals.

\begin{tabular}{lrrrrrrr}
\hline Year & 1967 & 1968 & 1969 & 1970 & 1971 & 1972 & 1973 \\
Deaths & 122 & 134 & 127 & 101 & 124 & 114 & 82 \\
Per cent mortality & 13.0 & 14.1 & 13.2 & 10.9 & 12.6 & 13.5 & 9.6 \\
\hline
\end{tabular}

TABLE III

Number and percentage of deaths of resident birds.

\begin{tabular}{lrrrrrrr}
\hline Year & 1967 & 1968 & 1969 & 1970 & 1971 & 1972 & 1973 \\
Deaths & 345 & 235 & 206 & 255 & 249 & 204 & 250 \\
Per cent mortality & 16.9 & 11.7 & 10.3 & 12.5 & 13.2 & 11.5 & 13.2 \\
\hline
\end{tabular}

\section{NUMBER AND PERCENTAGE OF DEATHS}

It must be pointed out that no figure given above is completely exact. All figures could be considered as estimates, as exact as possible. The number of deaths is arrived at by adding up the number of post-mortems of resident animals and the number of animals which have disappeared or whose carcasses have decomposed. An animal is considered to be resident when it has finished isolation or quarantine or, if born or hatched in the zoo, when it is three months old. Included may be young mammals and birds which, within three months of birth, are difficult to distinguish from adults. When calculating the mortality rate, the total number of animals in the collection at December 31st added to the number of deaths in the preceding year is taken as 100 . Disregarded are mammals and birds bought, sold, born and died under about three months of age (see tables VI and VII).

\section{MAMMALS}

The comparatively high death rates in 1967-1969 are caused by a high rate of infectious diseases, in 1972 by a high percentage of respiratory diseases (see: causes of death). The low rate in 1973 is about evenly distributed over all causes of death. The average for seven years is $12.4 \%$. Comparison with death rates of other zoos, sometimes calculated in a different way, reveal the following: Oklahoma City Zoo (1966) 12.8\%. The same report mentions an average of $16.9 \%$ for 11 other zoos. Washington (1970-1971) states in their report $16.6 \%$ and at the Cheyenne Mountain Zoological Park (1971) the average for the years $1967-1971$ is $9.7 \%$.

\section{BIRDS}

The high figure in 1967 is mostly caused by the extremely high number of birds that died from an infectious disease. In 1971 tuberculosis, botulism and egg-binding occurred more often than in other years (see: Causes of death). The average for these seven years is $13 \%$. Comparison over the same years with other zoos shows the following figures: Oklahoma City Zoo (1966): 18\%, and an average of 11 other zoos: $15.6 \%$. Washington (19701971 ) scores $15.3 \%$, and the Cheyenne Mountain Zoological Park an average for the years 1967 . 1971 of $15.2 \%$. 
TABLE IV

Causes of death - Mammals.

\begin{tabular}{|c|c|c|c|c|c|c|c|c|c|c|c|c|c|c|}
\hline \multirow[t]{2}{*}{ Causes of death } & \multicolumn{7}{|c|}{ Number } & \multicolumn{7}{|c|}{ Percentage } \\
\hline & 1967 & 1968 & 1969 & 1970 & 1971 & 1972 & 1973 & 1967 & 1968 & 1969 & 1970 & 1971 & 1972 & 1973 \\
\hline Infection & 39 & 46 & 58 & 28 & 31 & 15 & 22 & 32.0 & 34.3 & 45.7 & 27.7 & 25.0 & 13.2 & 26.8 \\
\hline Pasteurella, Yersinia & 15 & 22 & 32 & 8 & 9 & 12 & 9 & & & & & & & \\
\hline Salmonella & 8 & 3 & 6 & 1 & 3 & 3 & 6 & & & & & & & \\
\hline Erysipalis & 1 & 8 & 3 & 1 & 一 & - & - & & & & & & & \\
\hline Tuberculosis & 一 & 1 & 3 & 1 & 1 & - & 1 & & & & & & & \\
\hline Toxoplasmosis & 8 & 3 & 一 & 6 & 一 & 一 & 一 & & & & & & & \\
\hline Others & 7 & 9 & 14 & 11 & 18 & 一 & 6 & & & & & & & \\
\hline Alimentary & 11 & 13 & 5 & 10 & 10 & 7 & 9 & 9.0 & 9.7 & 3.9 & 9.9 & 8.1 & 6.1 & 10.9 \\
\hline Injury & 11 & 10 & 6 & 4 & 15 & 5 & 4 & 9.0 & 7.5 & 4.7 & 4.0 & 12.1 & 4.4 & 4.9 \\
\hline Respiratory & 9 & 14 & 7 & 12 & 5 & 22 & 11 & 7.3 & 10.4 & 5.5 & 11.9 & 4.0 & 19.3 & 13.4 \\
\hline Liver & 7 & 10 & 6 & 7 & 2 & 7 & 4 & 5.7 & 7.5 & 4.7 & 6.9 & 1.6 & 6.1 & 4.9 \\
\hline Parasitic worms & 11 & 1 & - & 6 & 3 & 1 & 1 & & & & & & & \\
\hline Urinary & - & 1 & 一 & 4 & 5 & 6 & 8 & 30.4 & 16.4 & 22.9 & 23.8 & 20.2 & 18.5 & 19.5 \\
\hline Circulation & 7 & 4 & 3 & 2 & 6 & 5 & 1 & & & & & & & \\
\hline Other causes & 19 & 16 & 26 & 12 & 11 & 9 & 6 & & & & & & & \\
\hline Not identified & 8 & 19 & 16 & 16 & 36 & 37 & 16 & 6.6 & 14.2 & 12.6 & 15.8 & 29.0 & 32.4 & 19.5 \\
\hline Total & 122 & 134 & 127 & 101 & 124 & 114 & 82 & 100 & 100 & 100 & 100 & 100 & 100 & 100 \\
\hline
\end{tabular}

TABLE V

Causes of death - Birds

\begin{tabular}{|c|c|c|c|c|c|c|c|c|c|c|c|c|c|c|}
\hline \multirow[t]{2}{*}{ Causes of death } & \multicolumn{7}{|c|}{ Number } & \multicolumn{7}{|c|}{ Percentage } \\
\hline & 1967 & 1968 & 1969 & 1970 & 1971 & 1972 & 1973 & 1967 & 1968 & 1969 & 1970 & 1971 & 1972 & 1973 \\
\hline Infection & 110 & 42 & 33 & 38 & 56 & 53 & 50 & 31.9 & 17.9 & 16.0 & 14.9 & 22.5 & 26.0 & 20.0 \\
\hline Pasteurella, Yersinia & 9 & 7 & 7 & 1 & 4 & 14 & 6 & & & & & & & \\
\hline Salmonella & 8 & 6 & 4 & 7 & 4 & 4 & 4 & & & & & & & \\
\hline Erysipalis & 3 & 8 & 2 & 3 & - & 3 & - & & & & & & & \\
\hline Tuberculosis & 9 & 7 & 4 & 5 & 10 & 3 & 3 & & & & & & & \\
\hline Coccidiosis & 6 & 1 & 1 & 4 & 2 & 6 & 11 & & & & & & & \\
\hline Mycosis & 8 & 5 & 4 & 6 & 9 & 13 & 9 & & & & & & & \\
\hline Virus & 61 & - & - & - & - & 3 & - & & & & & & & \\
\hline Others & 6 & 8 & 11 & 12 & $\left.27^{1}\right)$ & 7 & $\left.17^{2}\right)$ & & & & & & & \\
\hline Alimentary & 47 & 34 & 29 & 51 & 52 & 24 & 36 & 13.6 & 14.5 & 14.1 & 20 & 20.9 & 11.7 & 14.4 \\
\hline Injury & 46 & 42 & 36 & 26 & 28 & 19 & 24 & 13.3 & 17.9 & 17.5 & 10.2 & 11.3 & 9.3 & 9.6 \\
\hline Respiratory & 14 & 17 & 14 & 12 & 14 & 16 & 9 & 4.0 & 7.2 & 6.8 & 4.7 & 5.6 & 7.8 & 3.6 \\
\hline Urinary \& egg-binding & 24 & 27 & 20 & 15 & 30 & 11 & 14 & 7.0 & 11.5 & 9.7 & 5.9 & 12.1 & 5.4 & 5.6 \\
\hline Parasitic & 13 & 10 & 6 & 17 & 9 & 16 & 31 & 3.8 & 4.3 & 2.9 & 6.7 & 3.6 & 7.9 & 12.4 \\
\hline Liver & 11 & 5 & 19 & 16 & 5 & 9 & 13 & 3.2 & 2.1 & 9.2 & 6.2 & 2.0 & 4.4 & 5.2 \\
\hline Circulation & 6 & 5 & 5 & 4 & 6 & 4 & 3) & & & & & & & \\
\hline Neoplasms & 7 & 3 & - & 2 & 5 & 2 & $2\}$ & 8.7 & 10.6 & 9.2 & 6.6 & 10.4 & 7.9 & 6.0 \\
\hline Other causes & 17 & 17 & 14 & 11 & 15 & 10 & $10)$ & & & & & & & \\
\hline Not identified & 50 & 33 & 30 & 63 & 29 & 40 & 58 & 14.5 & 14.0 & 14.6 & 24.7 & 11.6 & 19.6 & 23.2 \\
\hline Total & 345 & 235 & 206 & 255 & 249 & 204 & 250 & 100 & 100 & 100 & 100 & 100 & 100 & 100 \\
\hline
\end{tabular}

1) Botulism $16 . \quad$ 2) Botulism 3. 


\section{CAUSES OF DEATH (tables IV and V)}

When a pathogenic micro-organism is cultured or parasites are found, the death is listed under this head. If not so the affected organs are listed. This means for instance that there will be more Salmonella than listed, since after a treatment with antibiotics, often no pathogenic organism is to be found. On the other hand, as there is clearly a general infection in a group and in the majority of cases the same strain of Salmonella is cultured, all deaths are listed under Salmonella. If more than one organ system is involved, one is chosen. "Not identified" in most cases means that only slight signs of disease could be found not allowing a firm conclusion. Sometimes there are no signs of any abnormality at all. Included are cases of advanced decomposition with no post-mortem done. Often the victims of stress will also be listed under this head.

\section{EPIZOOTICS}

Really serious epizootics are exceptional. It is our opinion that this is largely due to the fact that post-mortems are done as thoroughly as possible. As a consequence we are able to take preventive measures, e.g. treatment with anti-biotics of animals not yet sick and disinfecting pens with Halamid or natronlye if indicated. This is a standing rule when Salmonella, Pasteurella or Yersinia are cultured. Of course these measures are not always successful (see: Yersinia and virus). Animals in the same cage or/and, where necessary, those in adjacent cages, are treated with an antibiotic in the food, and especially in the case of birds, sometimes in the drinking water as well. Very often the pathogenic organism of an apparent infection remains unknown. In these cases we also made use of the above-mentioned antibiotics. When only a few animals are involved that can easily be injected either by hand or with the injection pistol, this method has preference.

\section{PASTEURELLA, YERSINIA}

During the years 1967, 1968 and 1969 we had many cases of Yersinia pseudotuberculosis in the nocturnal house. The normal treatment with antibiotics and disinfection did not stop the infection, which repeatedly returned. During 1969 a vaccine became available ${ }^{3}$ ). Early vaccination of healthy individuals proved successful. If even the slightest sign of disease had developed, vaccination was too late. In this year 32 mammals in the nocturnal house had died before vaccination started. For the rest of the year we only had one victim. As can be expected, however good the protection, it does not reach 100 percent. The vaccine was originally produced especially for the monkeys at Wassenaar Zoo, were it proved just as successful. In later years we have continued to use it where necessary.

\section{VIRUS}

As an example of the many things we still do not understand, we can give particulars of epizootics of psittacine birds and penguins. On February 10, 1967 , a parrakeet died in our Parrot House, on the 13th a cockatoo and two parrots followed in the course of the next four weeks by ten cockatoos, twenty-four parrots and nineteen parrakeets. During the following four weeks ten birds died with apparently similar although not clear symptoms. From the moment it could be seen that a bird was not well it lived in most cases only for a couple of hours more and certainly died the same day. Post-mortem showed in the great majority of cases no visible abnormality. In some cases only a slight swelling of the liver could be seen. Laboratory research did not reveal any clear cause of the illness, and it is classified here under the head "Virus" just to give it a name. Treatment of all the birds, shortly after the outbreak, did not produce any positive result (first Tylocine, later oxytetracycline in food and drinking water).

About the same time an unknown disease started up in the penguins, on the other side of the zoo. From March 3rd till July 1st we lost 12 Humboldt's, 5 Black-footed (Jackass), 1 Rockhopper and 1 Gentoo Penguin. Illness lasted one to five days and the symptoms pointed to an infection of the brain. An agent was isolated, pathogenic to baby mice injected in the brain. Histological examination showed degeneration of nerve cells and neurophagi. Adult mice did not react.

The death of three young and three adult Lesser Panda in 1970/1971 was the result of vaccinating

3) Prepared by the Veterinary Faculty of the University of Utrecht (Dr. P. Zwart). 
the young with live, frozen virus of dog distemper. The virus, used with good results in dogs, first caused the death of the young ones, which then infected their parents. The symptoms are quite different from those in dogs (Erken \& Jacobi, 1972).

\section{SKIN DISEASE}

It is interesting to record the story of a skin disease in our young apes, the cause of which is still unknown. It started after the introduction of two new Orang-outans in 1968 with a somewhat scaly skin. All the other apes (Chimpanzees, Gorillas and Orang-outans) were infected. Scratching, loss of hair and a grey coating on the skin were the symptoms and made our apes look awful. No cause could be found and no treatment showed good results. Gradually the symptoms became less and less but did not disappear completely until 1972 when the vitamin A and D supply was changed and unsaturated fatty acids (sun-flower seed oil) were given.

\section{WORMS}

Besides the normal causes of worm infection and treatment we had an interesting case with our Rock Hyrax. Some animals died from different causes (Salmonella, Pasteurella and others) but showed a rather heavy infection with the nematod Cobboldina. Earlier examination did not show any eggs in the faeces, so we thought that the infection had disappeared.

\section{DIABETES}

Some years before (1961) we lost our two Scimitar-horned Oryx (Oryx tao) with diabetes and later (1967) a Nilgai (Boselapbus tragocamelus). This is generally thought as a very rare disease in ruminants. In 1971 five Oryx tao, born in our zoo, died of Diabetes mellites as result of a pancreatic degeneration. Only two adult females remained unaffected (Erken, 1972). Information from other zoos led us to suspect the food as a possible cause of this illness in animals like Oryx which live on marginal semi-desert land. From then on we have only fed good quality hay and nothing else. A low ration of pellets is fed to pregnant and nursing females only. In 1976 the group (with a new male) has grown to seven animals, without further problems.

\section{COWPOX IN ELEPHANTS}

On August 9, 1973, our oldest female elephant, Barbara, of our group of one male and three females, showed small swellings on her trunk and suffered from a stiff right foreleg. The swellings disappeared in nine days. During this period she ate her food slowly and was often dozing. After 12 days only a little stiffness of her frontleg was evident and 17 days after the first signs of swelling she was her old self again. Only light patches on the skin gave a reminder of what had happened.

On August 23 the other two females, Suseela and Jumbo, showed smaller and bigger swellings all over. The same day Suseela had a swelling on her left foot above the toenails on the same place where there had been a slight inflammation at the end of May. The new inflammation deteriorated quickly and after one week (August 30) all four feet were inflamed. Loosening of the skin above the nails and discharge from all wounds was clearly visible. Besides a cleaning of the wounds with a water hose twice daily, injections with Kanaciline were given for seven days (per day 5 bottles, each containing $750 \mathrm{mg}$ Kanamycine base/2,250,000 I.E. Proc. penicillin G/750,000 I.E. penicillin G.Na), not only to cure the feet but also to prevent secondary infection (Pseudomonas) through the open swellings on the skin. All wounds were treated with cod liver oil ointment with an antibiotic. Behaviour, including walking, was normal. The only signs were that she felt a bit warm and took her food slowly in the first days of September. Three feet recovered quickly but the most seriously affected left foot needed more time. After losing two pieces of the sole of the foot at the beginning of October, complete recovery followed.

Presumably there is no direct connection between these foot troubles and the swellings on the skin. These stayed small with Jumbo and seemed to disappear after about five days. With Suseela they became bigger and bigger and spread all over in the same period. Only on August 30th, seven days after beginning, some swellings broke open and produced a discharge, like cowpox swellings, as 
indeed they proved to be (by Professor Gispen, Institute of Public Health). On September 8th Jumbo showed some new pox on back, sides and legs, and then a quick recovery set in. Suseela some days earlier had new pox on eyelids, upper jaw and palate, which, however, did not last long and did not interfere with feeding. The last new pox showed on October 9th ( 57 days after the first) but on October 27th the two females were able to join the other two elephants, completely healed. Our adult male has not been affected at all.

Why we have been so lucky, as cowpox can be very dangerous for elephants, we do not know. The animals did not show signs of serious illness and took their normal rations, if sometimes a bit slowly. Even the combination of foot troubles and cowpox in Suseela did not prove fatal. She was only a bit thin at the end.

\section{BIRTHS AND DEATHS}

\section{Mammals}

The number of mammals born in one year fluctuates between 164 and 249; the survival rate between $59 \%$ and $66 \%$.

When we look at the different groups we can make the following remarks. The percentage of surviving primates seems too low as it is never higher than $63 \%$.

TABLE VI

Mammals born and living after three months (Rabbits, Guinea Pigs, etc. excluded).

\begin{tabular}{|c|c|c|c|c|c|c|c|c|c|c|c|c|c|c|c|c|c|c|c|c|c|}
\hline & \multicolumn{3}{|c|}{1967} & \multicolumn{3}{|c|}{1968} & \multicolumn{3}{|c|}{1969} & \multicolumn{3}{|c|}{1970} & \multicolumn{3}{|c|}{1971} & \multicolumn{3}{|c|}{1972} & \multicolumn{3}{|c|}{1973} \\
\hline & B & $\mathbf{S}$ & $\%$ & B & $\mathbf{S}$ & $\%$ & B & $\mathbf{S}$ & $\%$ & B & $\mathbf{S}$ & $\%$ & B & $\mathbf{S}$ & $\%$ & B & $\mathbf{S}$ & $\%$ & B & $\mathbf{S}$ & $\%$ \\
\hline Primates & 19 & 10 & 53 & 25 & 12 & 48 & 30 & 18 & 60 & 24 & 15 & 63 & 15 & 9 & 60 & 26 & 16 & 62 & 10 & 6 & 60 \\
\hline Carnivores & 55 & 36 & 65 & 68 & 43 & 63 & 60 & 35 & 58 & 68 & 42 & 62 & 62 & 32 & 52 & 78 & 49 & 63 & 74 & 40 & 54 \\
\hline Wild ruminants & 48 & 28 & 58 & 50 & 28 & 56 & 56 & 32 & 57 & 48 & 26 & 54 & 39 & 26 & 67 & 44 & 29 & 66 & 52 & 37 & 71 \\
\hline Sheep and goat & 34 & 27 & 79 & 26 & 20 & 77 & 32 & 25 & 78 & 33 & 24 & 73 & 20 & 17 & 85 & 18 & 13 & 72 & 13 & 12 & 92 \\
\hline Other hoofed animals & 10 & 4 & 40 & 1 & 1 & 100 & 一 & 一 & 一 & 7 & 2 & 29 & 4 & 4 & 100 & 3 & 2 & 67 & 5 & 5 & 100 \\
\hline Rodents & 51 & 33 & 65 & 58 & 34 & 59 & 30 & 24 & 80 & 26 & 15 & 58 & 19 & 17 & 89 & 34 & 28 & 82 & 32 & 20 & 63 \\
\hline Other mammals & 15 & 6 & 40 & 21 & 8 & 38 & 13 & 5 & 38 & 12 & 10 & 83 & 5 & 3 & 60 & 12 & 4 & 33 & 9 & 2 & 33 \\
\hline Total & 232 & 144 & 62 & 249 & 146 & 59 & 221 & 139 & 63 & 218 & 134 & 62 & 164 & 108 & 66 & 215 & 141 & 66 & 195 & 122 & 63 \\
\hline
\end{tabular}

B = all animals born including premature and still births.

$\mathrm{S}=$ animals surviving after three months.

$\%=$ percentage of animals surviving.

\section{TABLE VII}

Birds hatched and living after three months (domestic birds, common Guineafowl and Japanese Quail excluded).

\begin{tabular}{|c|c|c|c|c|c|c|c|c|c|c|c|c|c|c|c|c|c|c|c|c|c|}
\hline & \multicolumn{3}{|c|}{1967} & \multicolumn{3}{|c|}{1968} & \multicolumn{3}{|c|}{1969} & \multicolumn{3}{|c|}{1970} & \multicolumn{3}{|c|}{1971} & \multicolumn{3}{|c|}{1972} & \multicolumn{3}{|c|}{1973} \\
\hline & B & $\mathbf{S}$ & $\%$ & B & $\mathbf{S}$ & $\%$ & B & $\mathbf{S}$ & $\%$ & B & $\mathbf{S}$ & $\%$ & B & $\mathbf{S}$ & $\%$ & B & $\mathbf{S}$ & $\%$ & B & $\mathbf{S}$ & $\%$ \\
\hline Pheasants & 125 & 83 & 66 & 46 & 36 & 78 & 18 & 10 & 56 & & & & 28 & 16 & 57 & 11 & 6 & 55 & 35 & 20 & 57 \\
\hline Other Gallinaceous & & & & & & & & & & 40 & 27 & 68 & & & & & & & & & \\
\hline birds & 43 & 33 & 77 & 17 & 11 & 65 & 7 & 6 & 86 & & & & 6 & 0 & 0 & 20 & 13 & 65 & 87 & 57 & 66 \\
\hline Ducks & 87 & 52 & 60 & 145 & 106 & 73 & 144 & 36 & 25 & 142 & 85 & 60 & 185 & 145 & 78 & 169 & 141 & 83 & 170 & 141 & 83 \\
\hline Geese & 6 & 5 & 83 & 9 & 6 & 67 & 21 & 15 & 71 & 14 & 9 & 64 & 11 & 5 & 45 & 16 & 14 & 88 & 18 & 17 & 94 \\
\hline Psittacine birds & - & - & - & - & - & - & 39 & 33 & 85 & - & - & - & 21 & 12 & 57 & 50 & 43 & 86 & 8 & 8 & 100 \\
\hline Plovers, etc. & - & - & - & - & - & - & - & - & - & 一 & - & - & 24 & 14 & 58 & 19 & 14 & 74 & 32 & 19 & 59 \\
\hline Aviary birds & - & - & - & 一 & - & - & - & - & - & 一 & - & - & 43 & 14 & 33 & 40 & 16 & 40 & 54 & 23 & 43 \\
\hline Penguins & 11 & 6 & 55 & 15 & 14 & 93 & 22 & 14 & 64 & 21 & 12 & 57 & 20 & 12 & 60 & 27 & 18 & 67 & 24 & 20 & 83 \\
\hline Others & 66 & 54 & 82 & 90 & 67 & 74 & 60 & 39 & 65 & 108 & 67 & 62 & 21 & 9 & 43 & 26 & 19 & 73 & 36 & 23 & 64 \\
\hline Total & 338 & 233 & 69 & 322 & 240 & 75 & 311 & 153 & 49 & 325 & 200 & 62 & 359 & 227 & 63 & 378 & 284 & 75 & 464 & 328 & 71 \\
\hline
\end{tabular}

B = all birds hatched.

$\mathrm{S}=$ birds surviving after three months.

$\%$ - percentage of surviving birds.

Where - is marked, the number is not separately counted and included in "Others". 
Causes of losses are of course different and complicated. They are: behaviour of the female, aggressive cage mates, not enough milk production and different diseases. We hope to reduce the losses. This is doubtful in carnivores as here the breeding facilities are of paramount importance and if not accepted by the female, a whole litter is often lost. We were also not content with a survival rate of about $56 \%$ of the ruminants born. As a Clostridium was found in several cases, we tried vaccination, but without result. The reason for this failure was later clear, as the vaccine proved not to give protection against the Clostridium septica prevailing in our zoo. Neither did Yatren against anaerobic infections and gammaglobulin injections show any results. Then we concentrated on feeding. An extra dose of Vitamins A and D in 1970 did not show any results either. The feeding in 1971 of extra minerals to pregnant and nursing females proved successful and the survival rate rose to $67 \%$.

Another improvement was brought about by stopping animals eating sand during the first weeks of life, by keeping them under the supervision of a keeper when out in the paddock. As in some cases white muscle disease was found we also started using injections of vitamin $E$ and selenium. We think that a $75 \%$ survival rate is possible.
Birds

The number of birds hatched is in general not unsatisfactory and much higher than in former years (compare: 1959-1966, 147 a year; 1967$1973,335)$. Of course many things are still not as they should be and often the survival rate is too low.

The accommodation for breeding ducks had been improved greatly, resulting in more eggs hatched and a survival rate of $83 \%$ in recent years. This result is reached by collecting the eggs from the enclosures and brooding them under Japanese silky hens. The hatching itself occurs in the incubator and the ducklings of about the same age are kept in boxes with a heating lamp and running water during the first weeks in the "incubator house". But still better results could be achieved. As an example: from 363 eggs (in 1971) 32 disappeared, 67 were not fertile and 79 ducklings died before hatching. As a result only 185 ducklings hatched, not much more than $50 \%$. The very bad result in 1969 was due to infectuous diseases in the first week. Improving the conditions of hygiene during the following years reduced the risk of death.

We do not understand why most of the Rothschild's Myna born in our Zoo do not survive and why Picathartes have young every year but have only once succeeded in bringing them up. We have not yet succeeded in finding the solution of these problems.

\section{REFERENCES \\ and other papers consulted}

AMSTERDAM, 1967-1973. Jaarverslag van de Stichting tot Instandhouding van de Diergaarde van het Koninklijk Zoölogisch Genootschap Natura Artis Magistra.

BERLIN, 1967-1973. Jahresbericht des Zoologischen Gartens.

Cheyenne Mountain Zoological Park, 1971. Annual Report.

ERKEN, A. H. M., 1972. Glykosurie mit Pankreasatrophie bei Antilopen im Amsterdamer Tiergarten "Natura Artis Magistra". Einige klinische und pathologische Aspekte. Verhandl.ber. internat. Symp. Erkrankungen Zootiere, 14 (Wroclaw).

ERKen, A. H. M. \& E. F. JACOBI, 1972. Successful breeding of Lesser Panda (Ailurus fulgens F. Cuvier, 1825) and loss through inoculation. Bijdr. Dierk., 42 (1): 92-95.

ERKRANKUNGEN der Zoo Tiere, 1967. Verhandl.ber. internat. Symp. Erkrankungen Zootiere, 9 (Prag).
- 1968. Verhandl.ber. internat. Symp. Erkrankungen Zootiere, 10 (Salzburg).

JACOBI, E. F. \& G. M. SMITS, 1968. Report on veterinary matters, births and deaths at the Amsterdam Zoo, 1959 1966. Bijdr. Dierk., 37: 3-10.

Jersey, 1972. Annual Report, The Jersey Wildlife Preservation Trust.

London, 1972. Annual Report of the Zoological Society of London.

NoRTh OF England Zoological Society. Veterinary Laboratory Annual Report, Chester Zoological Gardens, 1969, 1971, 1972.

Oxlahoma Citx, 1966. Annual Zoo Report.

Phil.adelphia, 1973. Annual Report Zoological Garden.

WAshington, 1970-1971. Annual Report National Zoological Park, Smithsonian Institute. 